\title{
Communication
}

[Comunicação]

\section{Cheilospirura hamulosa (Diesing, 1851) (Nematoda, Acuarioidea) in turkeys in Brazil: occurrence and pathology}

[Cheilospirura hamulosa (Diesing, 1851) (Nematoda, Acuarioidea) em perus no Brasil: ocorrência e patologia]

\author{
B. Brener ${ }^{1}$, R. Tortelly ${ }^{2}$, L.C. Muniz-Pereira ${ }^{1}$, R.M. Pinto ${ }^{1,3}$ \\ ${ }^{1}$ Instituto Oswaldo Cruz \\ Av. Brasil, 4365 \\ 21045-900 - Rio de Janeiro, RJ \\ ${ }^{2}$ Faculdade de Veterinária - UFF - Niterói, RJ \\ ${ }^{3}$ Bolsista do $\mathrm{CNPq}$
}

In spite of its high pathogenicity, there are only a few available studies of the lesions that Cheilospirura hamulosa provokes in the infected hosts. Investigations mostly refer to microscopic injuries in chickens worldwide and pheasants from Hawaii (Menezes et al., 2003). The present finding is related to the occurrence and microscopic lesions associated to the presence of C. hamulosa in the turkey that represents a new host record for this nematode in Brazil, since the species had previously been reported in turkeys from the USA and Iraq.

Fifteen specimens of turkeys (Meleagris gallopavo), seven males, eight females weighing $2,200 \mathrm{~g}-7,350 \mathrm{~g}$ from backyard flocks of four localities of the State of Minas Gerais, were investigated. Three of the hosts were from Juiz de Fora, six from Teixeiras, five from Caratinga and one from Candeias. After individual clinical evaluation birds were euthanized and necropsied according to ethical procedures. Gizzards were dissected in a $0.85 \% \mathrm{NaCl}$ solution and the cuticle was removed for helminth investigation. Nematodes were collected, rinsed in the same solution, fixed with hot AFA (alcohol $70^{\circ} \mathrm{GL}$, $93 \mathrm{ml}$; formaldehyde, $5 \mathrm{ml}$; acetic acid, $2 \mathrm{ml}$ ).

Specimens were clarified in acetic acid and phenol, preserved in Canada balsam and deposited in the helminthological collection of the Oswaldo Cruz Institute (CHIOC), number 36402 a-b (whole mounts). Fragments of the parasitized gizzards were removed and immediately fixed in formalin. The material was then processed for paraffin embedding. Five micrometers thick sections were stained with hematoxylin and eosin. Classification of the nematodes to the species level was in accordance to Vicente et al. (1995). Micrographs were obtained in a Zeiss Axiophot brightfield microscope, by means of a differential contrast interference (DIC) system.

The etiological agent of cheilospirurosis in birds is the nematode C. hamulosa (Fig. 1.1 and 1.2) that parasitizes gizzards; specimens are found free under the gizzard cuticle, partially or fully burrowed in the walls of the organ, mainly in the region of the caudal blind sac (Fig. 1.3). The occurrence of $C$. hamulosa in the investigated turkeys was of $6.7 \%(1 / 15)$ and considering that only three worms were found in a same host, values referring to the mean intensity and range of infection are not applicable in this case.

Cheilospirurosis did not result in clinical signs in this study. The microscopic lesions of the gizzard were severe and characterized by intense chronic diffuse inflammatory mixed granulocyte infiltrations, extending to the muscular layers; moreover, in this area, it was possible to detect fragments of the parasite (Fig. 1.4); together with these fragments, perforation of the mucosa was also observed (Fig. 1.5). 


\section{Brener et al.}
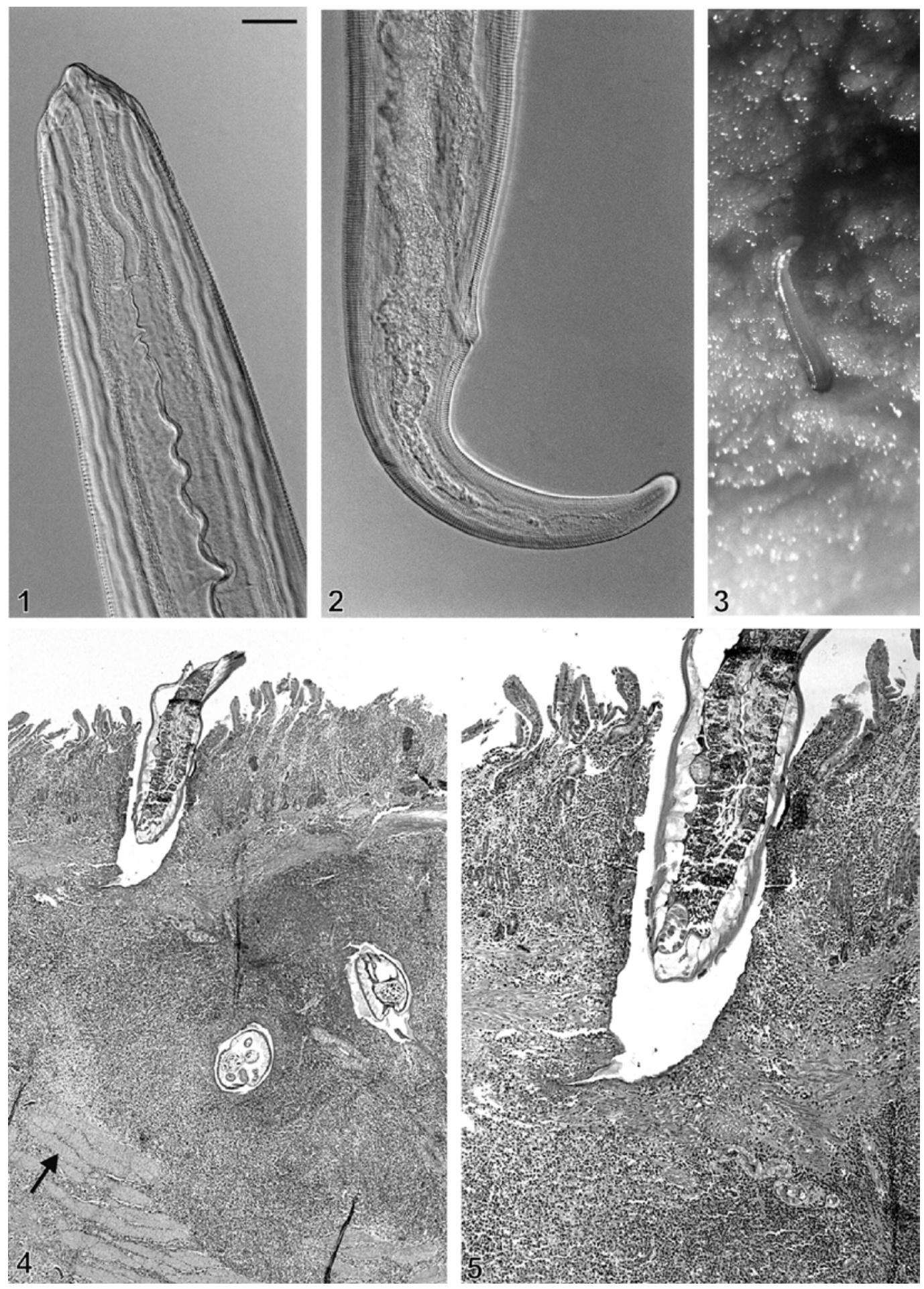

Figure 1. Cheilospirurosis in turkeys. 1 - Anterior portion of a female of $C$. hamulosa, ventral view. Bar $=0.1 \mathrm{~mm}$. (Bar of 1.1 is common to 1.2-1.5). 2 - Posterior portion of a female of C. hamulosa, lateral view. Bar $=0.1 \mathrm{~mm}$. 3 - Specimen of $C$. hamulosa burrowed in the gizzard mucosa. Bar $=0.5 \mathrm{~mm}$. 4 - Extensive inflamatory process and destruction of the muscular layer of the gizzard (arrow) with multiple fragments of specimens of $C$. hamulosa in the mucosa and in the exudates. Bar $=0.3 \mathrm{~mm} .5$ - Perforation site in the mucosa and submucosa caused by C. hamulosa. Bar $=0.1 \mathrm{~mm}$ 
Anemia, emaciation and death together with microscopic lesions in chickens and ring-necked pheasants parasitized with $C$. hamulosa have been reported by Alicata (1947) and Menezes et al. (2003). The latter authors affirm that even low parasite burdens of this nematode can provoke an inflammatory reaction that interfere in the muscular contraction, rotatory and crushing movements, affecting the mechanic digestion and food absortion by the hosts.

The definitive hosts for C. hamulosa are mainly galliform birds (Grisi and Carvalho, 1974; Hodasi, 1976; Cruz, 1981; Menezes et al., 2003). The turkeys parasitized with $C$. hamulosa did not present clinical signs; gross examinations did not reveal the presence of the yellowish and soft nodules that were previously observed in chickens and ring-necked pheasants by Alicata (1947), Fatihu et al. (1992) and Menezes et al. (2003). Although not detected in the single infected bird, the presence of these nodules can determine the rejection of the gizzard for food according to the Brazilian police of industrial and sanitary inspection of animal products (Ministério... 1997) and is a cause of economic loss (Mulder et al., 1997); thus, the finding of this pathogenic nematode species in free-range turkeys raised in Brazil may be of importance considering its potential risk for poultry industry and could deserve its inclusion in poultry health monitoring. Occurrences of $2.0 \%$ in turkeys from Iraq (Al-Alouisi et al., 1994) and of $6.7 \%$ in the present study may vary and in other galliform hosts can reach values up to $84.6 \%$ (Cruz, 1981, Menezes et al., 2003). C. hamulosa was also reported in turkeys in the USA, with no remarks related to the induced pathology (Hall, 1924).

In spite of the absence of epithelioid cell granulomas surrounding sections of the parasites in the serosa and muscular layer, as well as multinucleate giant cells surrounding necrotic sites as observed by Menezes et al. (2003), the lesions induced by $C$. hamulosa were severe and similar to those previously described; nevertheless, the low occurrence of a mild infection observed in this host (three parasites), suggests that in turkeys, the development of the infection may differ from what occurs in other galliform hosts and that turkeys are partially resistant to infections with $C$. hamulosa, taking into account that only two other cases of infection with this nematode species have been so far reported from this host worldwide.

Keywords: turkey, pathology, parasitism, Meleagris gallopavo, Cheilospirura hamulosa

\section{RESUMO}

Relata-se o primeiro caso de infecção de perus, Meleagris gallopavo, por Cheilospirura hamulosa no Brasil, com base no achado de três espécimes fêmeas de C. hamulosa, inseridos na submucosa da moela de um peru, retirado de um lote de 15 aves, provenientes de criadouros domésticos no estado de Minas Gerais. A ocorrência foi de 6,7\%. A ave parasitada não apresentava sinais clínicos. As lesões microscópicas da moela eram severas, caracterizando-se por intensos processos inflamatórios crônicos e difusos, com infiltrados mistos de granulócitos, estendendo-se à mucosa e às camadas musculares. Nessa área, foram observados fragmentos dos parasitos e perfuração da mucosa, com destruição das camadas musculares.

Palavras-chave: peru, patologia, parasitismo, Meleagris gallopavo, Cheilospirura hamulosa

\section{REFERENCES}

AL-ALOUSI T.I.; DAOUDI, M.S.; ALBAYATI, M.M. A study of endoparasites of turkeys in Mosul-Iraq. Iraq J. Vet. Sci., v.7, p.23129, 1994

ALICATA, J.E. Parasites and parasitic diseases of domestic animals in the Hawaiian Islands.
Pacific Sci., v.1, p.69-84, 1947.

CRUZ, E.H. Comunicacion sobre una considerable extensión de invasión por Cheilospirura hamulosa en aves ponedoras (1966). Ciênc. Tec. Agric. Vet., v.3, p.67-69, 1981.

FATIHU, M.Y.; OGBOGU, V.C.; NJOKU, C.O. et al Observations on lesions associated with 
some gastrointestinal nematodes of chickens in Zaria, Nigeria. Bull. Anim. Health Produc. Afr., v.40, p.15-18, 1992.

GRISI, L.; CARVALHO, L.P. Prevalência de helmintos parasitos de Gallus gallus domesticus L., no estado do Rio de Janeiro. Rev. Bras. Biol.,v.34, p.115-118, 1974.

HALL, M.C. The turkey as a host for Cheilospirura hamulosa. J. Parasitol., v.10, p.209, 1924.

HODASI, J.K.M. The helminth parasites of the helmet guinea fowl (Numida meleagridis galeata Pallas) in Ghana. Bull. Anim. Health Prod. Afr., v.24, p.81-87, 1976.

MENEZES, R.C.; TORTELLY, R.; GOMES ,
D.C. et al. Pathology and frequency of Cheilospirura hamulosa (Nematoda, Acuarioidea) in Galliformes hosts from backyard flocks. Avian Pathol., v.32, p.151-156, 2003.

MINISTÉRIO da Agricultura e do Abastecimento. Regulamento de Inspeção Industrial e Sanitária de Produtos de Origem Animal. DIPOA. Brasília, 1997.

MULDER, R.W.A.W.; VELDKAMP, T.; SIMONS, P.C.M. Turkey meat production and food safety in the next century. Turkeys, v.45, p.18-20, 1997.

VICENTE, J.J.; RODRIGUES, H.O.; GOMES, D.C. et al. Nematóides do Brasil. Parte IV: Nematóides de aves. Rev. Bras. Zool., v.12, p.1$273,1995$. 